\title{
Hydrogeochemical and Characteristics of Groundwater in Teluk Nilap Area, Rokan Hilir, Riau
}

\author{
Fitri Mairizki ${ }^{1, *}$, Arief Yandra Putra ${ }^{2}$, Widya Adiza Putri ${ }^{1}$, Ferdyansyah $^{1}$ \\ ${ }^{1}$ Department of Geological Engineering, Faculty of Engineering, Univeristas Islam Riau, Pekanbaru, Indonesia \\ ${ }^{2}$ Department of Chemistry Education, Faculty of Teacher Training and Education, Universitas Islam Riau, Pekanbaru, Indonesia \\ * Corresponding author : fitrimairizki@eng.uir.ac.id \\ Tel.:+62-852-7897-3771 \\ Received: Nov 21, 2021; Accepted: Dec 24, 2021 \\ DOI: 10.25299/jgeet.2021.6.4.8136
}

\begin{abstract}
Groundwater plays important role as the main water resource for human needs. The vulnerability of groundwater to contaminants both naturally and by human activities can be not avoided as a trigger for groundwater quality degradation. Hydrogeochemical become important highlights in groundwater studies because groundwater conditions in quality and quantity influenced by the geological formation of rock minerals in aquifer. Naturally, the condition of the research area which consists of peat swamps can also affect the characteristics of groundwater. The aims of this research are to determine groundwater types and groundwater facies in study area with an analytical approach using stiff diagram and piper diagram. The method used was purposive sampling by collecting data from dug wells at the research site. 5 samples from dug wells were used as representatives in the groundwater facies analysis. The groundwater facies analysis was carried out by measuring the concentration of major ions such as $\mathrm{Na}, \mathrm{K}, \mathrm{Ca}, \mathrm{Mg}, \mathrm{Cl}, \mathrm{SO}_{4}$, and $\mathrm{HCO}_{3}$. The highest groundwater level was in the northern part of study area $(7,84 \mathrm{~m})$ while the lowest groundwater level was in the southwest part of study area $(2,05 \mathrm{~m})$. The results showed three types of groundwater based on stiff diagram as sodium chloride $(\mathrm{NaCl})$, sodium sulfate $\left(\mathrm{NaSO}_{4}\right)$ and magnesium sulfate $\left(\mathrm{MgSO}_{4}\right)$. The lithology conditions that composed the aquifer affected the facies or origin of groundwater. The alluvium layer in the research area which rich in sodium $\left(\mathrm{Na}^{+}\right)$minerals with chloride $\left(\mathrm{Cl}^{-}\right)$or sulfate $\left(\mathrm{SO}_{4}{ }^{2-}\right)$ anions forms chloride sulfate facies $\left(\mathrm{Cl}+\mathrm{SO}_{4}\right)$ which were located in the middle to the south of the study area and sodium (potassium) chloride (sulfate) facies $\left(\mathrm{Na}(\mathrm{K}) \mathrm{Cl}\left(\mathrm{SO}_{4}\right)\right)$ which were distributed in the northern part of study area.
\end{abstract}

Keywords: Hydrogeochemical, groundwater type, groundwater facies, stiff diagram, piper diagram

\section{Introduction}

Groundwater plays important role because it has become the main water resource for human needs such as drinking water, domestic purposes, industrial, irrigation and the others (Taufiq et al., 2017). Groundwater is an economic and strategic commodity in several areas. It is estimated that $70 \%$ of population's clean water needs and $90 \%$ of industrial water needs come from groundwater. Groundwater has several advantages including groundwater quality relatively better than surface water and unaffected by the season, groundwater reserves easier to obtain, and it does not need network to distributed. On the other hand, the vulnerability of groundwater to contaminants both naturally and by human activities can be not avoided as a trigger for groundwater quality degradation (Mairizki, F., and Cahyaningsih, C., 2016). The presence of pollutants from garbage disposal area (Satrio, 2017), industrial activities (Naslilmuna et al., 2018) and agriculture or domestic waste (Sasongko et al., 2014) are some factors that causing a decrease in both on the quality and quantity of groundwater.

Utilization activities, management, monitoring and evaluation of groundwater resources must refer to the standards that have been set. For this reason, many research has been carried out on monitoring groundwater quality which used as a source of drinking water in various countries (Annapoorna, H., and Janardhana, M., R., 2015); (Lalitha et al., 2016); (Khan, A., and Khan, M., A., 2018); (Ibrahim, M., N., 2019); (Siringoringo et al., 2019); (Mairizki, F., et al., 2020).

Hydrogeochemical become important highlights in groundwater studies. This due to groundwater conditions in quality and quantity influenced by the geological formation of rock minerals that will form chemical elements or compounds. The interaction between groundwater and rock minerals in aquifer will dynamically affect the process of groundwater hydrogeochemical. There have been a lot of studies on hydrology, geochemistry and characteristics of groundwater (Hadian et al., 2017); (Dianardi et al., 2018); (Afriyani et al., 2020); (Putra, D., B., E., et al., 2021). Therefore, the aims of this research are to determine groundwater types and groundwater facies in study area with an analytical approach using stiff diagram and piper diagram.

\section{Study Area}

Teluk Nilap Village is located in Kubu Babussalam Subdistrict, Rokan Hilir, Riau Province. Topographically, this village is low land with altitude about $6-10 \mathrm{~m}$ from sea level and groundwater source depth $\leq 5 \mathrm{~m}$. The people use groundwater for domestic purposes. However, the people in the study area feel a change in environmental condition including the decrease of groundwater quality. Based on previous research, there were known that most of groundwater in the study area was yellow-brown in color (Putra, A., Y., and 
Mairizki, F., 2019), had an acidic pH (Putra, A., Y., and Mairizki, F., 2020), and contained Fe metal in high level (Putra, A., Y., and Mairizki, F., 2020).

According to regional physiography, the study area is a part of Central Sumatra Basin which consist of two formation including older superficial deposits $(\mathrm{Qp})$ and young superficial deposits (Qh) (Fig.1). The older superficial deposits consist of clays, vegetation rafts, silts and clayey gravels. On the other hand, young superficial deposits composed by clays, silts and clean gravels, vegetation rafts and peat swamps.

Astronomically, the research area is located between $2^{\circ} 0$ '27.82' '-2 ${ }^{\circ} 1$ '48.56" North Latitude and 100 $37^{\prime} 24.65^{\prime \prime}$ $100^{\circ} 38^{\prime} 43.84$ " East Longitude with an area $\pm 6,78 \mathrm{~km}^{2}$ and 15 dug wells as samples (Fig.2).

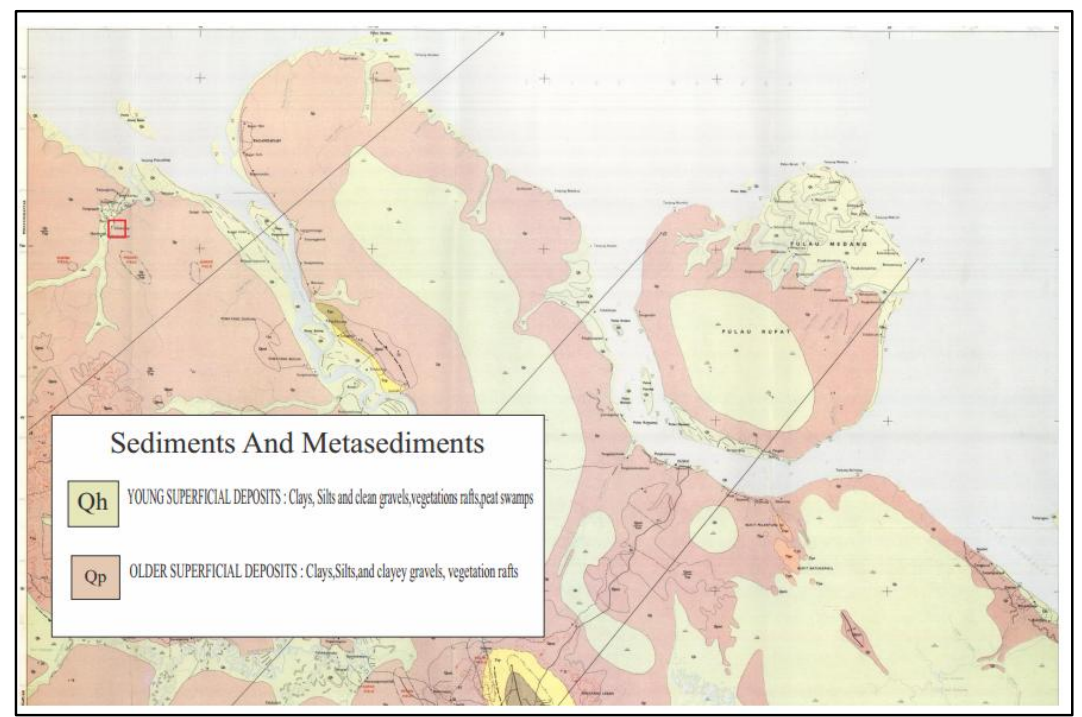

Fig. 1. Regional Geological Map of Study Area

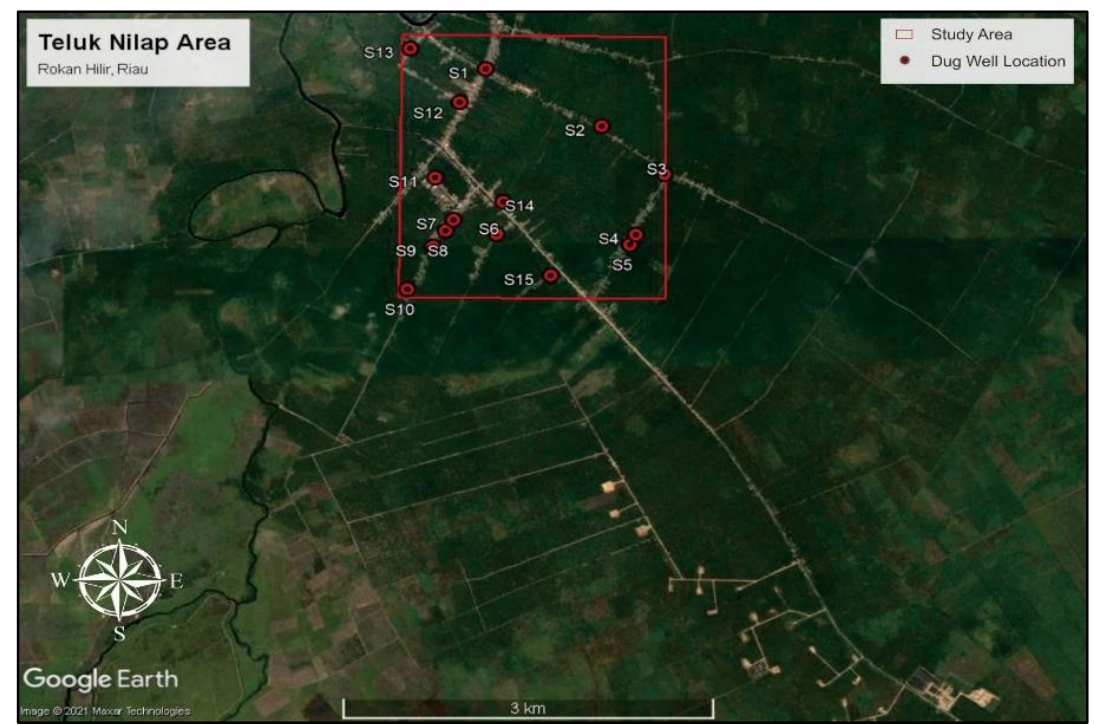

Fig. 2. Dug Well Location Map of Study Area

\section{Methodology}

The method used was purposive sampling by collecting data from dug wells at the research site. Groundwater level data such as topographic data, elevation and depth of dug wells were measured directly in the field. The groundwater types and facies analysis were carried out by measuring the concentration of major ions such as sodium $(\mathrm{Na})$, potassium $(\mathrm{K})$, calcium $(\mathrm{Ca})$, magnesium $(\mathrm{Mg})$, chloride $(\mathrm{Cl})$, sulfate $\left(\mathrm{SO}_{4}\right)$, and bicarbonate $\left(\mathrm{HCO}_{3}\right)$ at the Water Quality Laboratory, Faculty of Civil Engineering, Bandung Institute of Technology based on standard methods for the examination of water and wastewater (APHA). 5 samples from dug wells were used as representatives in the groundwater facies analysis.
Groundwater sampling using plastic bottle, the bottle must be full fill of groundwater, there should be no air bubbles in it, and the water temperature was kept in a stable condition to prevent the change of chemical component in water. The measurement results were analyzed by using Stiff diagram and Piper diagram. Stiff diagram was used to analyze dominant ions and groundwater types while Piper diagram was used to identification groundwater facies.

\section{Result and Discussion}

\subsection{Groundwater Flow Direction Map}

Groundwater flow direction map had been generated from measuring the groundwater elevation in each dug well. There 
were 15 dug wells measured in determining groundwater flow direction in research area. Groundwater elevation was in range 2,05-7,84 m (Table 1).

Table 1. Information of Groundwater Dug Well in Study Area

\begin{tabular}{ccc}
\hline Well ID & Depth $(\mathrm{m})$ & Groundwater Elevation $(\mathrm{m})$ \\
\hline S1 & 3,34 & 7,84 \\
S2 & 2,00 & 5,00 \\
S3 & 3,50 & 4,75 \\
S4 & 1,70 & 6,45 \\
S5 & 2,20 & 6,80 \\
S6 & 3,50 & 5,66 \\
S7 & 1,50 & 3,00 \\
S8 & 3,70 & 3,49 \\
S9 & 1,10 & 5,50 \\
S10 & 2,96 & 2,05 \\
S11 & 2,60 & 5,10 \\
S12 & 1,40 & 4,40 \\
S13 & 2,60 & 4,10 \\
S14 & 3,15 & 4,07 \\
S15 & 1,68 & 3,88 \\
\hline
\end{tabular}

Based on groundwater flow direction map (Fig.3), the northern part of research area has the highest groundwater elevation value, groundwater in this area flows in all directions to the locations with lower groundwater contours. The same thing happened in the southeastern part, where groundwater flows in all directions to locations with low groundwater contours. In contrast to the southwest, which has low groundwater level, this area gets groundwater recharge from all directions.

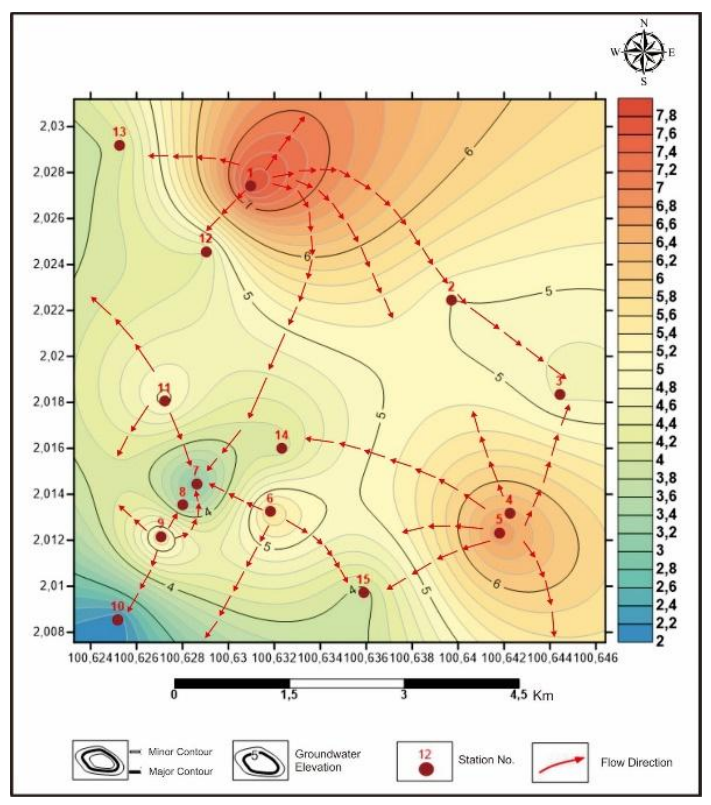

Fig.3. Groundwater Flow Direction Map

\subsection{Types and Facies of Groundwater}

The geochemistry of groundwater is affected by the geochemical reaction and water mixing or contamination from the surroundings. Groundwater changes, especially depending on the relationship with the rock type and water composition. Hydrogeochemical facies is one of the methods used to interpret flow patterns and origin of groundwater chemistry (Gemilang et al., 2019).

Hydrogeochemical analysis shows several major ions that have significant role in the groundwater characteristics. The dominant ions found were sodium and sulfate (Table 2) while the determination of groundwater facies uses the major ions concentration which has been converted into milliequivalents per liter (meq/L) (Table 3).
Table 2. Concentration of Each Major Ion in Groundwater Sample (mg/L)

\begin{tabular}{lccccccc}
\hline Well & \multicolumn{7}{c}{ Parameters (mg/L) } \\
\cline { 2 - 8 } ID & $\mathrm{Na}$ & $\mathrm{K}$ & $\mathrm{Ca}$ & $\mathrm{Mg}$ & $\mathrm{Cl}$ & $\mathrm{SO}_{4}$ & $\mathrm{HCO}_{3}$ \\
\hline S1 & 113 & 7,61 & 11,7 & 15,3 & 125 & 61,1 & 158 \\
S2 & 35,2 & 7,30 & 7,5 & 18,3 & 81,7 & 150 & 0 \\
S7 & 35,3 & 5,88 & 15 & 30,1 & 62,3 & 279 & 0 \\
S11 & 37,1 & 6,27 & 5,84 & 36,1 & 52,5 & 160 & 0 \\
S12 & 45,3 & 7,68 & 11,7 & 11,6 & 58,4 & 82,5 & 45 \\
\hline Max & 113 & 7,68 & 15 & 36,1 & 125 & 279 & 158 \\
\hline Min & 35,2 & 5,88 & 5,84 & 11,6 & 52,5 & 61,1 & 0 \\
\hline Aver & 53,18 & 6,95 & 10,35 & 22,28 & 75,98 & 146,52 & 40,6 \\
\hline
\end{tabular}

Table 3. Concentration of Each Major Ion in Groundwater Sample (meq/L)

\begin{tabular}{cccccccc}
\hline Well & \multicolumn{7}{c}{ Parameters (meq/L) } \\
\cline { 2 - 8 } ID & $\mathrm{Na}$ & $\mathrm{K}$ & $\mathrm{Ca}$ & $\mathrm{Mg}$ & $\mathrm{Cl}$ & $\mathrm{SO}_{4}$ & $\mathrm{HCO}_{3}$ \\
\hline S1 & 4,91 & 0,19 & 0,58 & 1,26 & 3,52 & 1,27 & 2,59 \\
$\mathrm{~S} 2$ & 1,53 & 0,19 & 0,37 & 1,50 & 2,30 & 3,13 & 0 \\
S7 & 1,53 & 0,15 & 0,75 & 2,48 & 1,75 & 5,81 & 0 \\
S11 & 1,61 & 0,16 & 0,29 & 2,97 & 1,48 & 3,33 & 0 \\
S12 & 1,97 & 0,19 & 0,58 & 0,95 & 1,64 & 1,72 & 0,74 \\
\hline Max & 4,91 & 0,19 & 0,75 & 2,97 & 3,52 & 5,81 & 2,59 \\
\hline Min & 1,53 & 0,15 & 0,29 & 0,95 & 1,48 & 1,27 & 0 \\
\hline Ave & 2,31 & 0,18 & 0,51 & 1,83 & 2,14 & 3,05 & 0,67 \\
\hline
\end{tabular}

The presence of abundant sodium was influenced by the rocks that composed its aquifer which are sedimentary rocks. Water trapped in sedimentary rock which is rich in clay minerals and stored for a long time will have sodium in high concentration. The presence of sulfate was found in sedimentary rocks in the form of sulfide minerals. When these minerals were weathered and contact with water, sulfur will be oxidized to sulfate ion which then dissolve in water.

The presence of potassium in groundwater was not dominant, especially since this element is difficult to separate from its silicate bonds. Some groundwater samples did not contain carbonate. This can be due to the high level of weathering in study area, the soil in humid climate area will have carbonate content that can be decrease because the leaching process.

\subsubsection{Stiff Diagram of Groundwater}

Stiff diagram shows the water type based on dominant cation and anion in groundwater samples. Several water types had found, such as Sodium Chloride $(\mathrm{NaCl})$, Sodium Sulfate $\left(\mathrm{NaSO}_{4}\right)$, and Magnesium Sulfate $\left(\mathrm{MgSO}_{4}\right)$. Sodium became governing cation to determined groundwater types, and sulfate became dominant anions that are ruling in determination groundwater types in research area (Fig. 4, Fig. 5, Fig. 6).

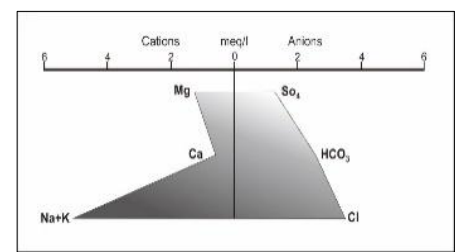

Fig.4. Stiff Diagram of Sodium Chloride Type (S1)

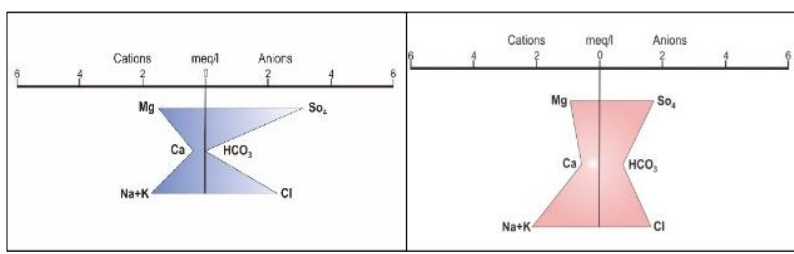

Fig.5. Stiff Diagram of Sodium Sulfate Type (S2, S12) 


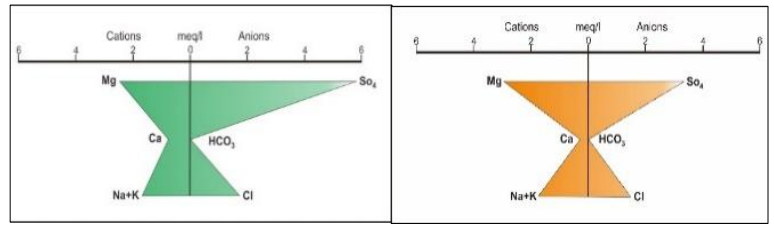

Fig.6. Stiff Diagram of Magnesium Sulfate Type (S7, S11)

\subsubsection{Piper Diagram of Groundwater}

Piper diagram used to identify the facies and evolution of groundwater in the study area. There are several groundwater facies determined from the cation triangle (left side), such as calcium type (A), sodium or calcium type (B), magnesium type (C) and no dominant type (D). Sodium or calcium type and magnesium type were the dominant type of groundwater from cation plot. On the other hand, there are several groundwater facies determined from the anion triangle (right side), there are bicarbonate type $(\mathrm{E})$, chloride type $(\mathrm{F})$, sulfate type $(\mathrm{G})$ and no dominant type $(\mathrm{H})$. Sulfate type was the most dominant type of groundwater from anion plot. Therefore, the diamond of piper diagram showed several groundwater facies namely chloride sulfate water (L) and sodium (potassium) chloride (sulfate) water (P) (Fig.7)

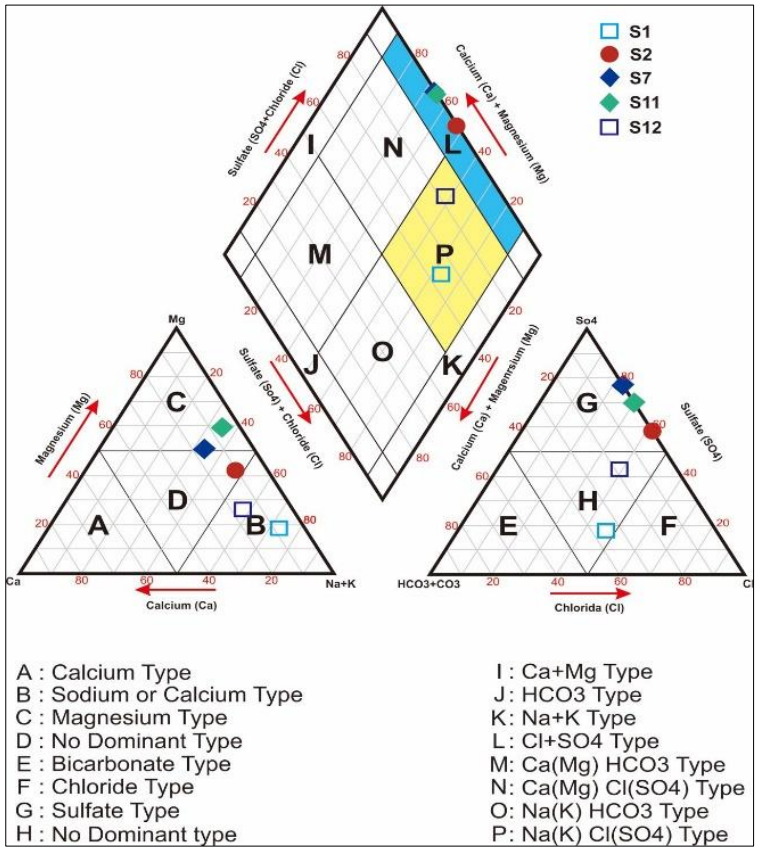

Fig 7. Piper Diagram of Groundwater Sample

Based on Fig.7, it can be seen that there were two types of groundwater facies in research area. The first facies as Alkaline Earth Water Higher Alkaline Content Predominantly Chloride with 3 sample points (L). This facies characterizes the groundwater content enriched by chloride brine and generally sediment rocks rich in $\mathrm{Na}^{+}$. The second facies as Alkaline Water Predominantly Sulfate-Chloride with 2 sample points (P). This facies characterizes the origin of groundwater mixed with chloride brine, as well as interaction of rocks that rich in clay minerals from $\mathrm{Na}^{+}$dominant alluvium layer. The research area that composed by alluvium layer rich in sodium $\left(\mathrm{Na}^{+}\right)$minerals with chloride $\left(\mathrm{Cl}^{-}\right)$or sulfate $\left(\mathrm{SO}_{4}{ }^{2-}\right)$ anions will form groundwater facies Alkaline Earth Water Higher Alkaline Content Predominantly Chloride or Alkaline Water Predominantly Sulfate-Chloride (Putranto et al., 2020).

\subsubsection{Groundwater Facies Distribution Map}

According to the analysis of major ion content, stiff diagram and piper diagram, the groundwater facies were divided into two types, namely $\mathrm{Na}(\mathrm{K}) \mathrm{Cl}\left(\mathrm{SO}_{4}\right)$ facies $(\mathrm{P} 1)$ and $\mathrm{Cl}+\mathrm{SO}_{4}$ facies $(\mathrm{P} 2) . \mathrm{Na}(\mathrm{K}) \mathrm{Cl}\left(\mathrm{SO}_{4}\right)$ facies were found in $\mathrm{S} 1$ and $\mathrm{S} 12$ which located in the northern part of study area while $\mathrm{Cl}+\mathrm{SO} 4$ facies were found in $\mathrm{S} 2, \mathrm{~S} 7$ and $\mathrm{S} 11$ which are located in the middle to the south of the study area (Fig.8).

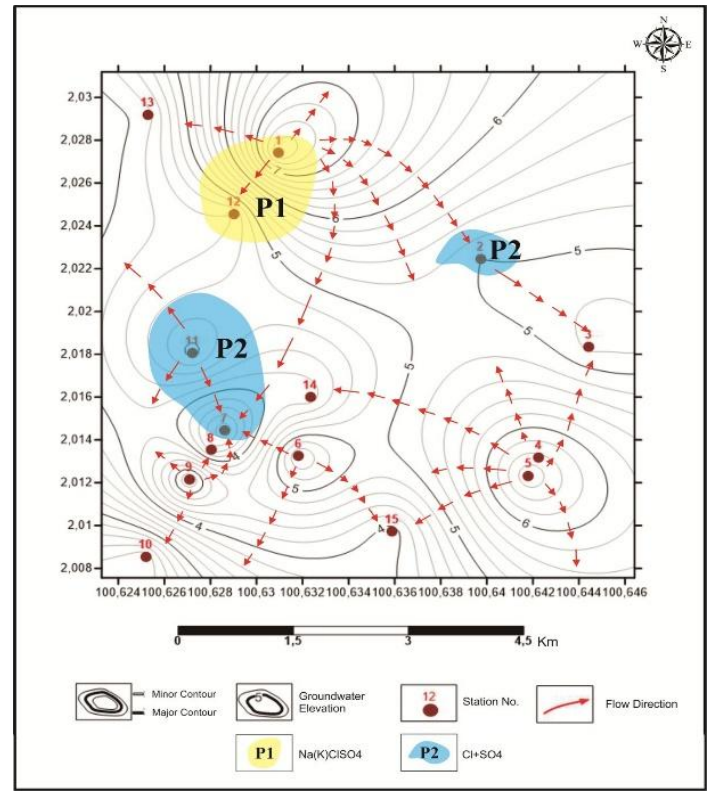

Fig 8. Groundwater Facies Distribution Map

\section{Conclussion}

Groundwater conditions in quality and quantity influenced by the geological formation of rock minerals in aquifer. The condition of research area which consists of peat swamps also affect the characteristics of groundwater. In conclusion, the highest groundwater level was in the northern part of study area at $\mathrm{S} 1(7,84 \mathrm{~m})$ while the lowest groundwater level was in the southwest part of study area at S10 $(2,05 \mathrm{~m})$. The results showed three types of groundwater based on stiff diagram as sodium chloride $(\mathrm{NaCl})$, sodium sulfate $\left(\mathrm{NaSO}_{4}\right)$ and magnesium sulfate $\left(\mathrm{MgSO}_{4}\right)$. The lithology conditions that composed the aquifer affected the facies or origin of groundwater. The alluvium layer in the research area which rich in sodium $\left(\mathrm{Na}^{+}\right)$minerals with chloride $\left(\mathrm{Cl}^{-}\right)$or sulfate $\left(\mathrm{SO}_{4}^{2-}\right)$ anions forms $\mathrm{Cl}+\mathrm{SO}_{4}$ facies which were located in the middle to the south of the study area and $\mathrm{Na}(\mathrm{K}) \mathrm{Cl}\left(\mathrm{SO}_{4}\right)$ facies which were distributed in the northern part of study area.

\section{Acknowledgements}

The authors would like to give an acknowledgment to Direktorat Penelitian dan Pengabdian Masyarakat (DPPM) Universitas Islam Riau as the funding of this research. Additional thank you for all students that help authors to collect data at field.

\section{References}

Afriyani, M., P., Santoso, L., W., Adji, T., J., N. 2020. Analisis Genesa Hidrogeokimia Airtanah Menggunakan Diagram Piper Segiempat di Wilayah Pesisir. MKG, 21(1), 1-11. http://dx.doi.org/10.23887/mkg.v20i2.213.

Annapoorna, H., Janardhana, M., R. 2015. Assessment of Groundwater Quality for Drinking Purpose in Rural Areas Surrounding a Defunct Copper Mine. Aquatic 
Procedia

4 ,

https://doi.org/10.1016/j.aqpro.2015.02.088.

Dianardi, K., Hadian, S., D., Iskandarsyah, Y., W., M., Muhamadsjah, F. 2018. Studi Hidrokimia dan Karakteristik Airtanah di Kecamatan Cibiru dan Cileunyi, Bandung, Jawa Barat, Indonesia. Bulletin of Scientific Contribution Geology, 16(2), 71-77.

Gemilang, W., A., Ridwan, N., N., H., Wisha, U., J. 2019. Karakteristik Hidrogeokimia Akuifer Tak Terkekang Kawasan Pesisir Pulau Weh, Aceh. Jurnal Sumber Daya Air, 15(1), 27-38.

Hadian, M., S., D., Waliyana, T., Y., Sulaksana, N., Putra, D., B., E., Yuskar, Y. 2017. Hydro Chemistry and Characteristics of Groundwater : Case Study Water Contamination at Citarum River Upstream. Journal of Geoscience, Environment, and Technology, 2(4), 268271. doi:10.24273/jgeet/.2017.2.4.4578.

Ibrahim, M., N. 2019. Assessing Groundwater Quality for Drinking Purpose in Jordan : Application of Water Quality Index. Journal of Ecological Engineering, 20(3), 101-11. https://doi.org/10.12911/22998993/99740.

Khan A., Khan M., A. 2018. Groundwater Assessment for Drinking Purpose in Gulistan-e-Johar Town, Karachi, Pakistan. Journal of Geoscience, Engineering, Environment, and Technology, 3(4), 200-207. doi: 10.24273/jgeet.2018.3.4.2086.

Lalitha, B., V., Teja, V., S., Rajesh, V. 2016. A study on Assessment of Groundwater Quality and Its Suitability for Drinking in Shivajipalem Area Visakhapatnam, A.P International Journal of Engineering Development and Research, 4(2), 1618-1621.

Mairizki, F., Cahyaningsih, C. 2016. Groundwater Quality Analysis in The Coastal of Bengkalis City Using Geochemistry Approach. International Journal of Engineering and High-End Technology, 1(2), 82-87.

Mairizki, F., Angga, R., P., Putra, A., Y. 2020. Assessment of Groundwater Quality for Drinking Purpose in an Industrial Area, Dumai City, Riau, Indonesia. 2021. Journal of Geoscience, Environment, and Technology, 5(4), 234-238. doi:10.25299/jgeet.2020.5.4.5983.

Naslilmuna, M., Muryani, C., Santoso, S. 2018. Analisis Kualitas Air Tanah dan Pola Konsumsi Masyarakat Sekitar Industri Kertas PT Jaya Kertas Kecamatan Kertosono Kabupaten Nganjuk. Jurnal GeoEco, 4(1), 51 58. https://doi.org/10.20961.ge.v4i1. 19176.

Putra, A.Y., Mairizki, F. 2019. Analisis Warna, Derajat Keasaman dan Kadar Logam Besi Air Tanah di Kecamatan Kubu Babussalam, Rokan Hilir, Riau. Jurnal
Katalisator, $\quad 4(1)$,

9-14. http://doi.org/10.22216/jk.v4i1.4024.

Putra, A.Y., Mairizki, F. 2020. Analisis Logam Berat pada Air Tanah di Kecamatan Kubu Babussalam, Rokan Hilir, Riau. Jurnal Katalisator, 5(1), 47-53. http://doi.org/10.22216/jk.v5i1.5277.

Putra, A.Y., Mairizki, F. 2020. Groundwater Quality Assessment for Drinking Purpose Based on Physicochemical Analysis in Teluk Nilap Area, Rokan Hilir, Riau. Indonesia. Journal of Geoscience, Environment, and Technology, 5(3), 170-174. doi:10.25299/jgeet.2020.5.3.5488

Putra, D., B., E., Hadian, M., S., D., Alam, B., Y., CSH., S., Yuskar., Y., Yaacob, W., Z., W., Datta, B., Harnum, W., P., D. 2021. Geochemistry of Groundwater and Saltwater Instrusion in a Coastal Region of an Island in Malacca Strait, Indonesia. 2021. Environ. Eng. Res., 26(2), 1-8. https://doi.org/10.4491/eer.2020.006.

Putranto., T., T., Hidajat, W., K., Prayudi, S., D. 2020. Pemetaan Hidrogeologi dan Analisis Geokimia Air Tanah Cekungan Air Tanah (CAT) Kendal. Jurnal Ilmu Lingkungan, 18(2), 305-318.

Sasongko, E., B., Widyastuti, E., Priyono, R., E. 2014. Kajian Kualitas Air dan Penggunaan Sumur Gali Oleh Masyarakat di Sekitar Sungai Kaliyasa Kabupaten Cilacap. Jurnal Ilmu Lingkungan, 12(2), 72-82. doi:10.14710/jil.12.2.72-82.

Satrio, Pujiindiyati, E., R. 2017. Karakteristik Air Tanah Akuifer Dalam Sekitar Tempat Pembuangan Sampah Terpadu (TPST) Bantar Gebang-Bekasi, Jawa Barat. Jurnal Teknologi Lingkungan, 18(1), 96-103. https://doi.org/10.29122/jtl.vl8il.48.

Siringoringo, L., P., Rizki, R., Nababan, J. 2019. Hydrogeochemical and Groundwater Assessment for Drinking Purpose at ITERA Campus Area and Its Surroundings. Journal of Geoscience, Engineering, Environment, and Technology, 4(1), 40-48. doi:10.25299/jgeet.2019.4.1.2478.

Taufiq., A., Hosono, T., Ide, K., Kagabu, M., Iskandar, I., Hutsoit, A., M., Shimada, J. 2017. Impact of Excessive Groundwater Pumping on Rejuvenation Processes in the Bandung Basin (Indonesia) as Determined by Hydrogeochemistry and Modeling. Hydrogeology Journal, 26(4), 1263-1279. http://dx.doi.org/10.1007/s10040-017-1698-8.

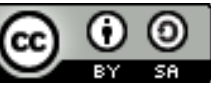

(C) 2021 Journal of Geoscience, Engineering, Environment and Technology. All rights reserved. This is an open access article distributed under the terms of the CC BY-SA License (http://creativecommons.org/licenses/by-sa/4.0/). 